\title{
AN ANOMALY WITHIN AN ANOMALY: THE HALLOWEEN EFFECT IN THE LONG-TERM REVERSAL ANOMALY
}

\section{King Fuei Lee ${ }^{*}$}

1. Schroder Investment Management, Singapore

* Corresponding Author: Lee King Fuei, Co-Head of Asian Equity Alternative Investments, Schroder Investment Management, Singapore 048946, Tel: (+65) 6800 7000, $₫$ Email: king.lee@schroders.com

\begin{abstract}
In this study, we investigated the presence of the Halloween effect in the long-term reversal anomaly in the US. After examining the cross-sectional returns of losers-minus-winners portfolios formed on prior returns over the period of 1931-2021, we found evidence of stronger returns during winter months versus summer months. Specifically, the effect appeared to be driven by a significant winter-summer seasonality in the portfolio of small-capitalisation losers and a lack of the Halloween effect in the portfolio of large-capitalisation winners. This study's results were found to be robust with respect to alternative measures of the long-term reversal effect, differing sub-periods, the inclusion of the January effect and outlier considerations, as well as regarding small- and large-sized companies.
\end{abstract}

Keywords: Halloween effect, Sell-in-May, long-term reversal, market anomaly

\section{Introduction}

The efficient market hypothesis (EMH) is one of the most influential theories in modern financial history. It is primarily attributed to Fama (1970), who posited that it is impossible to beat the market consistently on a risk-adjusted basis since asset prices reflect all available public information. Since his seminal work, many studies have unearthed and investigated market anomalies, which are essentially time-series or cross-sectional patterns in security returns that defy the rules of the EMH.

Over the past two decades, the Halloween effect, one of the most prominent seasonal market anomalies, has confounded market participants. This is also known as the 'Sell in May and go away' puzzle. Originally a part of a longer adage, 'Sell in May and go away, but buy back on St Leger's Day', this saying is believed to have originated in the period when City of London stockbrokers would escape their desks to enjoy the hot summer season that included many sporting and social festivities. With a paucity of market participants, the month of May thus heralds the beginning of a period of lacklustre market returns such that investors find it more rewarding to simply sell their stocks and hold cash. However, as St Leger's Day approaches in mid-September, investors are advised to re-enter stock markets in anticipation of a period of strong returns over the winter months. A pioneering study investigating the existence of a seasonal effect based on this old market adage was conducted by Bouman and Jacobsen (2002), who examined 37 developed and emerging markets over the period from January 1970 to August 1998 and found that the winter returns (November to April) were substantially higher than the summer returns (May to October) in 36 of these countries. According to them, this Halloween anomaly cannot be explained by data mining, the January effect, risk, sectorspecific factors, news provision, or shifts in interest rates or trading volume. In an updated and extended form of this work, Zhang and Jacobsen (2021) investigated the Halloween effect from September 1998 to November 2011 by using the same 37 countries in Bouman and Jacobsen (2002) and found evidence of the continued presence of the Halloween effect in all of these countries, with 15 of them displaying statistically significant estimates. They also extended their analysis to 109 stock markets using a combined period spanning 323 years and found the mean returns from NovemberApril to be higher than the mean returns from May-October in 82 of these countries. Their finding is 
interesting, because contrary to the predictions of the EMH and Schwert (2002), it seems that the 'Sell in May' anomaly has not been arbitraged away by rational investors even after the effect has been documented and publicised.

The prevalence of the Halloween effect is not only restricted to the national stock market indices. Arendas (2017) analysed 20 major agricultural commodities from 1980 to 2015, and found that 15 out of the 20 commodities, including corn, cotton, palm oil, and soybean, recorded higher average mean winter returns than summer returns. Burakov et al. (2018) performed a similar analysis on the energy markets over the period of 1985-2016 and found statistically significantly higher winter returns in the majority of these markets. Additionally, many studies have been conducted on the Halloween effect in the cross-sections of stock returns of numerous stock markets. For example, Jacobsen and Visaltanachoti (2009) examined sectors and industries within the US stock market during 1926-2006 and observed that 48 out of the 49 industries investigated performed better during the winter months as compared to the summer months, with two-thirds of these industries showing a statistically significant Halloween effect. On the other hand, Jacobsen et al. (2005) analysed US portfolios formed on size, dividend yield, book-to-market, earnings yield, and cash flow yield. They found that all the portfolios in their study showed higher mean winter returns and confirmed that the Halloween effect is a market-wide phenomenon.

In addition to the Halloween effect, another set of anomalies that have baffled EMH proponents are stock return anomalies, including the long-standing phenomenon, the long-term reversal effect. Originally hinted at by Jegadeesh and Titman (1993), who highlighted the U-shape of momentum returns across lengthening holding periods, the long-term reversal anomaly was formally introduced in the academic field by De Bondt and Thaler (1985), and it has since been confirmed by various studies, including Grinblatt and Moskowitz (2004) and Zaremba et al. (2020). Specifically, the longterm reversal anomaly refers to the tendency of stocks with low returns over the past 3-5 years to outperform stocks with high returns over the same time period. When De Bondt and Thaler (1985) examined the Center for Research in Security Prices (CRSP) monthly return data, they found that losers tended to earn approximately $25 \%$ more than winners 3 years after portfolio formation, despite the winners being significantly riskier. According to them, this phenomenon is consistent with the predictions of the overreaction hypothesis where individuals, in contradiction to Bayes' rule, 'overreact' to unexpected and dramatic news events in the short run, and subsequently correct for that overreaction in the long run. However, George and Hwang (2007) contested that the long-term reversal anomaly has more to do with tax loss harvesting than investor overreaction. In their view, as investors, due to the capital gains lock-in effect, have an incentive to delay selling their winners to avoid paying capital gains taxes, they demand higher reserve prices for the sale of these winners, which leads to winners having lower expected returns as compared to losers. Several other theoretical explanations for the existence of the anomaly have also been offered by researchers, including Daniel et al. (1998), Barberis et al. (1998), and Hong and Stein (1999). Regardless of the reasons for the long-term reversal effect, it is clear that the outperformance of losers versus winners in the long run remains a puzzle that intrigues researchers.

In recent years, a stream of research has emerged that investigates the Halloween anomaly within stock return anomalies. For instance, Fiore and Saha (2015) examined the seasonality of stock returns in low beta (low volatility) stocks and found that the low-risk anomaly appears only in summer months. Aver (2019) expanded on their work and investigated the winter-summer seasonality in other capital market anomalies of size, value, and momentum and beta in 21 developed stock markets. He found that the returns for the size and value (momentum and beta) anomalies tended to be higher in winter (summer) but pointed out that the results did not withstand statistical testing.

Therefore, our study adds to this growing stream of research by empirically investigating the seasonal Halloween effect in the long-term reversal anomaly. We found that the factor of mean monthly winter returns for the long-term reversal factor is statistically significantly higher than the mean monthly summer returns by $0.599 \%$. Specifically, the Halloween effect appeared to be strongest in the extremely long portfolio consisting of small-capitalisation losers, and non-existent in the short portfolio comprising large-capitalisation winners. The other long portfolio including large- 
capitalisation losers and short portfolio including small-capitalisation winners showed a similar Halloween effect. We also conducted several robustness checks. These included employing alternative measures of the long-term reversal factor, accounting for the January and outlier effects, considering the firm size effect, in addition to conducting a sub-period analysis. We found that the winter-summer seasonality of long-term reversal returns is robust with respect to all these considerations. Specifically, consistent with Zhang and Jacobsen (2021), this Halloween effect appears to have been highly significant since the 1960s.

The motivations for our study were twofold. First, while a few studies have examined the Halloween effect in the size, value, momentum and beta, and low-volatility anomalies (Aver, 2019; Fiore and Saha, 2015), to our knowledge, no study has explored this seasonality effect in the long-term reversal anomaly. Therefore, our study fills this gap and contributes to the current literature. Second, our study increases the understanding of the long-term reversal effect and will be of particular interest to practitioners and investors seeking to exploit this market anomaly. Specifically, our finding regarding the winter-summer seasonality in the long-term reversal anomaly indicates the potential of applying market timing when employing long-term reversal strategies to enhance the risk-return profile of these strategies.

Our paper is structured as follows: Section 2 discusses the data and regression model employed in the study. Section 3 presents the empirical findings and robustness checks. Finally, Section 4 concludes the paper.

\section{Data Sample and Methodology}

This section briefly discusses the data sources, definitions of variables, and the methodology used in this study.

Our study covered the sample period from January 1931 to May 2021, and the stock universe from which the portfolios were constructed included NYSE, AMEX and NASDAQ firms which had prior return data. Following Zaremba et al. (2020), we measured long-term reversal as the stock returns over the previous 5-year period, excluding the previous 1 year (from months $t-13$ to $t-60$ ). At the end of each month $t$, stocks were categorised into six value-weighted portfolios formed on size (measured as market equity) and prior returns. These six portfolios essentially represent the intersections of the two portfolios formed on size and the three portfolios formed on prior returns. The monthly size breakpoint is the median NYSE market equity, while the monthly prior return breakpoints are the $30^{\text {th }}$ and $70^{\text {th }}$ NYSE percentiles.

Subsequently, the long-term reversal factor (LT_REV) was constructed as a market-neutral portfolio comprising the average return on the two low prior return portfolios minus the average return on the two high prior return portfolios.

$$
L T \_R E V=1 / 2(\text { Small Losers }+ \text { Big Losers })-1 / 2(\text { Small Winners }+ \text { Big Winners })
$$

To investigate the statistical significance of the Halloween effect in the long-term reversal factor, we adopted the regression model employed by Bouman and Jacobsen (2002) and Zhang and Jacobsen (2021):

$$
r_{t}=\alpha+\beta H_{a l}+\varepsilon_{t}
$$

where $r_{t}$ is the continuously compounded monthly returns and Halt is the Halloween dummy that takes the value of 1 if month $t$ falls within the winter months of November through April, and 0 otherwise. Therefore, the regression coefficient $\beta$ represents the difference between the average returns of the two 6-month periods of November-April and May-October. If it is statistically significantly positive, it is inferred that the Halloween effect is present. 
All data used for our calculations were obtained from the website of Kenneth French 1.

\section{Empirical Findings}

Table 1 shows the main summary statistics of the long-term reversal factor. It is observed that over the entire sample period, the long-term reversal factor has delivered a statistically positive average monthly return of $0.288 \%$, indicating the existence of an anomaly in the US market. This finding is consistent with that of De Bondt and Thaler (1985) and Zaremba et al. (2020), who documented the outperformance of long-term losers to long-term winners. Interestingly, when our sample was split into two 6-month periods of winter months (November to April) and summer months (May to October), we observe that while the mean monthly returns factor remains statistically significantly positive in winter, the mean returns factor in summer is not statistically different from zero. This indicates that the long-term reversal anomaly is only prevalent during the months of November to April and not during the rest of the year, suggesting the existence of the Halloween effect.

Table 1: Summary Statistics

\begin{tabular}{|c|c|c|c|}
\hline & Whole period & $\begin{array}{l}\text { Winter months: } \\
\text { November-April }\end{array}$ & $\begin{array}{l}\text { Summer months: } \\
\text { May-October }\end{array}$ \\
\hline Mean & 0.288 & 0.586 & -0.013 \\
\hline Standard error & 3.454 & 3.511 & 3.372 \\
\hline t-statistic & $2.743^{* * *}$ & $3.894^{* * *}$ & -0.086 \\
\hline Maximum & 36.450 & 36.450 & 32.990 \\
\hline Minimum & -14.070 & -8.730 & -14.070 \\
\hline Skewness & 2.827 & 3.153 & 2.499 \\
\hline Kurtosis & 27.177 & 28.943 & 25.415 \\
\hline No. of observations & 1085 & 544 & 541 \\
\hline
\end{tabular}

Subsequently, " the Halloween effect regression analysis was conducted. Column 1 of Table 3 shows the results of the regression, where a positive Halloween effect is observed at the $1 \%$ significance level. Therefore, this study's results confirm the existence of the Halloween effect in the long-term reversal anomaly.

To further investigate the source of this seasonal effect in the long-term reversal anomaly, we examined the four individual portfolios that constitute the overall long-term reversal effect in Equation (1). We can observe from Table 2 that three out of the four portfolios exhibit statistically positive Halloween effects, with the long portfolio Small Losers showing the strongest Halloween effect and the short portfolio Big Winners showing no signs of the winter-summer seasonality. It is interesting to note that the magnitudes of the regression coefficients and t-statistics of the long portfolio Big Losers and short portfolio Small Winners are similar. This indicates that much of the Halloween effect that is observed in the long-term reversal anomaly in this study is driven by the strength of the Halloween effect (or lack of) in the extreme long (short) portfolios.

\footnotetext{
1 Available at https://mba.tuck.dartmouth.edu/pages/faculty/ken.french/data_library.html
} 
Table 2: Halloween effect in the Loser and Winner Portfolios

\begin{tabular}{lccc} 
& & Small & Size \\
\hline Long-term reversal & Losers & $1.473^{* * *}$ & Big \\
& & $(4.821)$ & $0.794^{* * *}$ \\
& Winners & $0.783^{* *}$ & $(2.598)$ \\
& & $(2.563)$ & 0.286 \\
& & $(4.821)$ \\
\hline
\end{tabular}

Note: This table provides the results from the Halloween effect regression $r_{+}=a+\beta H a l_{+}+\varepsilon+$ where $r_{+}$is the continuously compounded monthly returns. The dummy variable Hal t takes on the value 1 if month $t$ falls within the winter months of November-April and 0 otherwise. Long-term reversal is measured as the stock returns over the previous 5-year period excluding the previous 1 year, while Size is measured as the market capitalisation of the stocks. The results exhibited are derived from the regressions run on the portfolios formed on the intersections of Size and Long-term reversal. T-statistics are shown in parentheses and are based on the Newey-West (1987) heteroskedasticity and autocorrelation consistent covariance matrix. Significance levels: ${ }^{* * *}=1 \%,{ }^{* *}=5 \%, *=10 \%$.

\subsection{Robustness Checks}

To ensure that our results are robust, we performed a number of checks.

\subsubsection{Alternative Definitions of the Long-Term Reversal Factor}

In this study, we followed the conventional method employed in various studies, such as Fama and French (1993) and Carhart (1997) to construct the long-term reversal factor. This involved using valueweighted portfolios that are formed at the $30^{\text {th }}$ and $70^{\text {th }}$ percentile breakpoints to calculate losers minus winner returns. However, some papers have adopted different methods in constructing the anomaly factor. For example, George and Hwang (2007) and Zaremba et al. (2020) used equalweighted portfolios to calculate long-term reversal factor returns. Meanwhile, other studies such as Stambaugh and Yuan (2016) and Lettau and Pelger (2018) formed winner and loser portfolios by using decile breakpoints instead of tertile breakpoints.

Table 3: Halloween effect in in Long-term Reversal and Robustness Checks

\begin{tabular}{|c|c|c|c|c|c|c|c|c|c|}
\hline \multirow{3}{*}{$\begin{array}{l}\text { Dependent variable } \\
\text { Column }\end{array}$} & \multirow{3}{*}{ (1) } & \multicolumn{7}{|c|}{ Long-term reversal } & \multirow[b]{2}{*}{ (9) } \\
\hline & & (2) & (3) & & (5) & (6) & (7) & (8) & \\
\hline & & \multicolumn{8}{|c|}{ Robustness checks } \\
\hline \multicolumn{2}{|l|}{ Explanatory variables } & $\begin{array}{l}\text { Equal- } \\
\text { weighted } \\
\text { portfolios }\end{array}$ & $\begin{array}{l}\text { Decile } \\
\text { portfolios }\end{array}$ & $\begin{array}{l}\text { January } \\
+ \text { outliers }\end{array}$ & $\begin{array}{l}\text { Small } \\
\text { firms }\end{array}$ & $\begin{array}{l}\text { Big } \\
\text { firms }\end{array}$ & $\begin{array}{l}1931- \\
1960\end{array}$ & $\begin{array}{l}1961- \\
1990\end{array}$ & $\begin{array}{l}1991- \\
2021\end{array}$ \\
\hline Halloween effect dummy & $\begin{array}{l}0.599^{* * *} \\
(3.195)\end{array}$ & $\begin{array}{c}0.761^{* * *} \\
(3.704)\end{array}$ & $\begin{array}{l}1.301^{* * *} \\
(3.617)\end{array}$ & $\begin{array}{l}0.298^{* *} \\
(2.240)\end{array}$ & $\begin{array}{l}0.690^{* * * *} \\
(3.872)\end{array}$ & $\begin{array}{l}0.508^{* *} \\
(2.166)\end{array}$ & $\begin{array}{c}0.294 \\
(0.693)\end{array}$ & $\begin{array}{c}0.872^{* * *} \\
(3.246)\end{array}$ & $\begin{array}{l}0.631^{* *} \\
(2.065)\end{array}$ \\
\hline \multirow[t]{2}{*}{ January effect dummy } & - & - & - & $1.520^{* * *}$ & - & - & - & - & - \\
\hline & - & - & - & (3.975) & - & - & - & - & - \\
\hline \multirow{2}{*}{ Outlier dummy } & - & - & - & $8.570^{* * *}$ & - & - & - & - & - \\
\hline & - & - & - & (4.478) & - & - & - & - & - \\
\hline Intercept & $\begin{array}{c}-0.013 \\
(-0.084)\end{array}$ & $\begin{array}{c}0.054 \\
(0.346)\end{array}$ & $\begin{array}{l}-0.157 \\
(-0.541)\end{array}$ & $\begin{array}{l}-0.187^{*} \\
(-1.839)\end{array}$ & $\begin{array}{c}-0.012 \\
(-0.084)\end{array}$ & $\begin{array}{c}-0.014 \\
(-0.072)\end{array}$ & $\begin{array}{c}0.263 \\
(0.675)\end{array}$ & $\begin{array}{c}-0.161 \\
(-0.938)\end{array}$ & $\begin{array}{l}-0.138 \\
(-0.721)\end{array}$ \\
\hline No. of observations & 1085 & 1085 & 1085 & 1085 & 1085 & 1085 & 360 & 360 & 365 \\
\hline $\begin{array}{l}\text { Note: This table provides th } \\
\text { compounded monthly retu } \\
\text { November-April and } 0 \text { othe } \\
\text { and } 0 \text { otherwise. The Outlier } \\
\text { monthly returns is greater } \\
\text { excluding the previous } 1 \text { ye } \\
\text { equal-weighted tertile portf } \\
\text { January effect dummy an } \\
\text { capitalisation and large-can } \\
\text { statistics are shown in parent }\end{array}$ & $\begin{array}{l}\text { e results } f \\
\text { ns. The du } \\
\text { wise. The } \\
\text { dummy vo } \\
\text { lan } 2.50 \text {. } \\
\text { ar. Column } \\
\text { lios, and } \\
\text { the Outl }\end{array}$ & $\begin{array}{l}\text { om the Ho } \\
\text { mmy varia } \\
\text { anvary eff } \\
\text { riable take } \\
\text { ong-term r } \\
\text { s (1) and ( } \\
\text { alue-weig } \\
\text { or dummy }\end{array}$ & $\begin{array}{l}\text { loween eff } \\
\text { ble Hal tak } \\
\text { ct dummy } \\
\text { the value } \\
\text { eversal is } \mathrm{m} \\
\text { ) show the } \\
\text { ted decile } \\
\text { are includ }\end{array}$ & $\begin{array}{l}\text { ect regressi } \\
\text { es on the v } \\
\text { variable tak } \\
\text { f } 1 \text { when the } \\
\text { easured as } \\
\text { results wher } \\
\text { portfolios re } \\
\text { d. Column }\end{array}$ & $\begin{array}{l}\text { on } r_{f}=a \\
\text { alue } 1 \text { if } r \\
\text { es on the } \\
\text { absolute } \\
\text { the stock } \\
\text { the long } \\
\text { spectively } \\
\text { (5) and }\end{array}$ & $\begin{array}{l}\text { BHal }+ \text { }+\varepsilon \\
\text { honth } t \text { fal } \\
\text { value of } 1 \\
\text { value of th } \\
\text { returns ov } \\
\text { term rever } \\
\text { Column } \\
\text { ) show th }\end{array}$ & $\begin{array}{l}\text { where } \\
\text { Is within } \\
\text { if the mo } \\
\text { e within-s } \\
\text { er the pr } \\
\text { sal facto } \\
\text { 4) shows } \\
\text { e results }\end{array}$ & $\begin{array}{l}\text { is the cc } \\
\text { he winter } \\
\text { th } t \text { falls } \\
\text { ample Z-sc } \\
\text { evious } 5-y \\
\text { is constru } \\
\text { the results } \\
\text { for using }\end{array}$ & $\begin{array}{l}\text { months } 0 \\
n \text { Januar } \\
\text { ore of the } \\
\text { ar perioc } \\
\text { :ted usins } \\
\text { when the } \\
\text { nly smal }\end{array}$ \\
\hline
\end{tabular}


Therefore, we checked the robustness of our results by adopting alternative measures of the longterm reversal factor. This was accomplished in two ways. First, we recalculated the factor returns by using equal-weighted portfolios instead of value-weighted portfolios. The calculation followed the same form as in Equation (1). Thus, Column 2 of Table 3 shows the results of the Halloween effect regression on the equal-weighted long-term reversal factor. It is observed that the Halloween effect remains statistically positive. In the second test, we calculated the long-term reversal factor by using the bottom decile portfolio minus the top decile portfolio formed on prior returns. It is observed from Column 3 of Table 3 that the Halloween effect remains positive at $1 \%$ significance level. The magnitude of the Halloween dummy regression coefficient in this column is also considerably larger than that in Column 1, indicating a stronger Halloween effect in the long-term reversal factor when extreme portfolios are used to form the factor. This reinforces our earlier finding that extreme portfolios are responsible for driving much of the seasonal effect observed in the stock return anomaly and shows that our finding is robust with respect to alternative measures of the long-term reversal factor.

\subsubsection{January Effect and Outliers}

Maberly and Pierce (2005) contended that an analysis of the Halloween effect using equation (2) ignores two important influences: the January effect and the presence of outliers, which can dramatically impact the regression results.

Previous studies (Haugen and Lakonishok, 1988; Rozeff and Kinney, 1976) have found that stock returns tend to be unusually large in January. Specifically, when De Bondt and Thaler (1987), in the follow-up study to their 1985 study that reported the discovery of the long-term reversal anomaly, acknowledged that long-term reversals tend to display a very strong seasonal pattern, with losers typically showing significant reversals only in January. This strong seasonality of long-term reversals was similarly observed by Grinblatt and Moskowitz (2004), who documented strong January reversals for long-term losers. This poses a risk because the conventional definition of the winter period used in most studies includes the period from November to April. This period encompasses January, which therefore raises the possibility that observations of the Halloween effect might simply be largely driven by the anomalous January returns. Therefore, it is important to consider the impact of the January effect.

In addition to the January effect, Maberly and Pierce (2005) highlighted the potential of outliers to distort the results of any Halloween effect analysis. For example, when they studied the Halloween effect in the US market, they found that the low average returns observed during the summer months were predominantly driven by two outlier events: the Stock Market Crash of 1987, which occurred in October 1987, and the Long-Term Capital Management Fund Crisis, which occurred in August 1998. When they controlled for the impact of these outliers, the Halloween effect in the US market became statistically insignificant.

To control for the January effect as well as the impact of outliers, they proposed that the Halloween effect be investigated by using the following regression model:

$$
r_{t}=\alpha+\beta_{1} \text { Hal }_{t}+\beta_{2} \text { Jan }_{t}+\beta_{3} \text { Outlier }_{t}+\varepsilon_{t}
$$

where Jant is the January effect dummy that takes the value of 1 if month $t$ falls in January and 0 otherwise. The variable Outliert is the outlier dummy, which takes the value of 1 when the absolute value of the within-sample Z-score of the monthly returns is greater than 2.50 . 
Following the methodology of Maberly and Pierce (2005), we performed regressions using Equation (3). Our results are demonstrated in Column 4 of Table 3, where it is observed that the Halloween effect in the long-term reversal anomaly remains statistically positive even when considerations for the January effect and outliers are included. This confirms that the Halloween effect remains prevalent in the mean returns of the long-term reversal anomaly, even when we control for the January effect and the impact of outliers.

\subsubsection{Firm size Effect}

According to Zarowin (1990), smaller companies have a greater tendency of becoming loser firms because losers, by definition, are firms that have lost market share to winners. In his study of US companies over the period from 1932 to 1977, he found that the average size of losers was smaller than the average size of winners in 13 of the 17 non-overlapping 3-year periods under examination, and that 'the averages of the quintile ranks for losers and winners [also] show that losers tend to be among the smaller firms, while winners tend to be among the larger ones'. Thus, he posited that much of the reversal phenomenon documented by De Bondt and Thaler (1985) is essentially only the firm size effect.

The finding of Zarowin (1990) is interesting as it raises the possibility that the Halloween effect that we have found in the long-term reversal anomaly in this study is simply a reflection of the same Halloween effect that Auer (2019) identified in the size anomaly. To check the robustness of our findings, we controlled for the size effect by investigating the long-term reversal factor by using portfolios of firms of similar sizes. This is executed by separately calculating long-term reversal factors for small- and large-capitalisation firms:

$$
\begin{aligned}
& L T_{-} R E V_{\text {Small }}=\text { Small Losers }- \text { Small Winners } \\
& L T_{-} R E V_{\text {Big }}=\text { Big Losers }- \text { Big Winners }
\end{aligned}
$$

Subsequently, we performed the Halloween effect regressions by using the two newly calculated factors. It is observed from Columns 5 and 6 of Table 3 that the Halloween effect in the long-term reversal anomaly within both small- and large-sized firms remains strongly positive. This indicates that the Halloween effect observed in the reversal phenomenon is not driven by the firm size effect.

\subsubsection{Sub-period Analysis}

To examine whether our findings are consistent over time, we divided our sample period into three sub-samples of approximately 30 years each. These three sub-samples span the period from January 1931 to December 1960, January 1961 to December 1990, and January 1991 to May 2021.

Columns 7-9 of Table 3 show the results of the regressions. It is discerned that the Halloween effect was not observed in the long-term reversal anomaly during the period of 1930-1960. However, the seasonal effect becomes much more pronounced in the long-term reversal anomaly from 1961 onwards, with the winter months delivering mean returns $+0.872 \%$ higher than during the summer months over the period of 1961-1990, and $+0.631 \%$ higher over the period-of 1991-2021. Interestingly, our finding of a more prevalent Halloween effect only after 1960 is similar to that of Zhang and Jacobsen (2021), who examined 65 international markets over 323 years and concluded that the Halloween effect only became statistically significant in the last 50 years, starting from the 1960 s. Therefore, this finding confirms the significant winter-summer seasonality in the long-term reversal effect in the last 60 years after 1960. 


\section{Conclusion}

Since the EMH was first proposed by Fama (1970), many studies have focused on uncovering market anomalies that defy the EMH rules. Specifically, the seasonal Halloween effect and the long-term reversal effect both represent peculiar puzzles for EMH proponents.

The objective of our study was to investigate the presence of an anomaly within an anomaly, specifically, the existence of the Halloween effect within the long-term reversal phenomenon. Using US data from January 1931 to May 2021, we found evidence of the existence of the winter-summer seasonality effect in the long-term reversal anomaly. Our work also showed that the effect appears to be driven by the extreme portfolios used to construct the anomaly, and that the Halloween effect has persisted since the 1960s. Additionally, we conducted a number of robustness checks and found our results to be robust to alternative definitions of the long-term reversal effect, the inclusion of the January effect and outlier dummies, and while controlling for the firm size effect, in addition to a differing sub-period analysis.

Therefore, our study contributes to the current literature by filling the gap in existing research regarding the Halloween effect within stock return anomalies and will be of particular interest to practitioners who are looking to exploit the long-term reversal effect in stock returns.

\section{References}

Arendas, P. 2017. The Halloween Effect on the Agricultural Commodities Markets. Agricultural Economics 63 (10): 441-448.

Aver, B. 2019. Does the Strength of Capital Market Anomalies Exhibit Seasonal Patterns?. Journal of Economics and Finance 43 (1), 91-103.

Barberis, N., A. Shleifer, and R. Vishny. 1998. A Model of Investor Sentiment. Journal of Financial Economics 49 (3): 307-343.

Bouman, S., and B. Jacobsen. 2002. The Halloween Indicator, "Sell in May and Go Away": Another Puzzle. American Economic Review 92 (5): 1618-1635.

Burakov, D., M. Freidin, and Y. Solovyev. 2018. The Halloween Effect on Energy Markets: An Empirical Study. International Journal of Energy Economics and Policy 8 (2): 121-126.

Carhart, M. 1997. On Persistence in Mutual Fund Performance. Journal of Finance 52 (1): 57-82.

Daniel, K., D. Hirshleifer, and A. Subrahmanyam. 1998. Investor Psychology and Security Market Underand Overreactions. Journal of Finance 53 (6), 1839-1885.

De Bondt, W., and R. Thaler. 1985. Does the Stock Market Overreact?. Journal of Finance 40 (3): $793-$ 805.

De Bondt, W., and R. Thaler. 1987. Further Evidence on Investor Overreaction and Stock Market Seasonality. Journal of Finance 42 (3): 557-581.

Fama, E., and K. French. 1993. Common Risk Factors in the Returns on Stocks and Bonds. Journal of Financial Economics 33 (1): 3-56. 
Fiore, C., and A. Saha. 2015. A Tale of Two Anomalies: Higher Returns of Low-Risk Stocks and Return Seasonality. Financial Review 50 (2): 257-273.

George, T., and C.Y. Hwang. 2007. Long-Term Return Reversals: Overreaction or Taxes?. Journal of Finance 62 (6): 2865-2896.

Grinblatt, M., and T. Moskowitz. 2004. Predicting Stock Price Movements from Past Returns: The Role of Consistency and Tax Loss Selling. Journal of Financial Economics 71 (3): 541-579.

Haugen, R.A., and J. Lakonishok. 1988. The Incredible January Effect: The Stock

Hong, H., and J. C. Stein. 1999. A Unified Theory of Underreaction, Momentum Trading, and Overreaction in Asset Markets. Journal of Finance 54 (6): 2143-2184.

Jacobsen, B., A. Mamun, and N. Visaltanachoti. 2005. Seasonal, Size and Value Anomalies. Massey University Department of Commerce Working Paper Series Issue 5.

Jacobsen, B., and N. Visaltanachoti. 2009. The Halloween Effect in U.S. Sectors. Financial Review 44 (3): 437-459.

Jegadeesh, N., and S. Titman. 1993. Returns to Buying Winners and Selling Losers: Implications for Stock Market Efficiency. Journal of Finance 48 (1): 65-91.

Lettau, M., and N. Pelger. 2018. Factors that Fit the Time Series and Cross-Section of Stock Returns. National Bureau of Economic Research Working Paper No. 24858.

Maberly, E., and R. Pierce. 2005. The Halloween Effect and Japanese Equity Prices: Myth or Exploitable Anomaly. Asia-Pacific Financial Markets 10 (4): 319-334.

Rozeff, M., and W. Kinney. 1976. Capital Market Seasonality: The Case of Stock Returns. Journal of Financial Economics 3 (4): 379-402.

Schwert, W.G. 2002. Anomalies and market efficiency. In G. M. Constantinides, M. Harris, \& R. M. Stulz (Eds.), Handbook of Economics and Finance. Amsterdam, Netherlands: North-Holland.

Stambaugh, R., and Y. Yuan. 2016. Mispricing Factors. Review of Financial Studies 30 (4): 1270-1315.

Zaremba, A., R. Kizys, and M.W. Raza. 2020. The Long-Run Reversal in the Long Run: Insights from Two Centuries of International Equity Returns. Journal of Empirical Finance 55 (C): 177-199.

Zarowin, P. 1990. Size, Seasonality and Stock Market Overreaction. Journal of Financial and Quantitative Analysis 25 (1): 113-125.

Zhang, C., and B. Jacobsen. 2021. The Halloween Indicator, "Sell in May and Go Away": Everywhere and All the Time. Journal of International Money and Finance 110 (C): 1-49. 